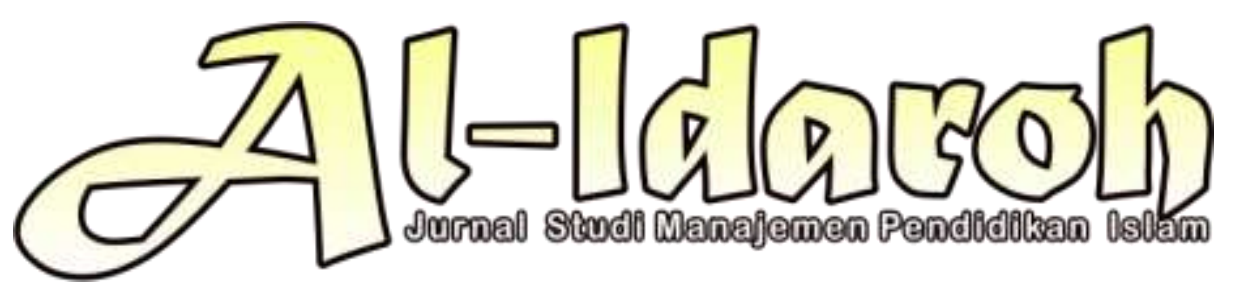

\title{
STRATEGI PEMBIAYAAN PADA LEMBAGA PENDIDIKAN ISLAM MELALUI TANGGUNG JAWAB SOSIAL (CSR) STUDI KASUS BANK BRI SYARIAH
}

\author{
Yayuk Purwati \\ Universitas Islam Negeri Sunan Kalijaga Yogyakarta \\ Email: Yayukpurwati96@gmail.com
}

\begin{abstract}
Social responsibility or Corporate Social Responsibility is not only to complement obligations based on law and morals, but it is also present as a strategy for society and the company to survive for a long time. If this Social Responsibility is eliminated it will have an impact on the company, one of which will bear a lot of financing. But if on the other hand the company carries out its Social Responsibility properly, including ensuring the distribution of financing fairly and correctly, then this will later lead to benefits in a long period of time for the company. BRI Syariah in carrying out CSR in the field of education provides a program called Education Benefits which aims to support the quality of education in the community. In 2018 the Company has carried out around 33 activities including: providing scholarship financing to outstanding students who are categorized as poor students in 9 universities, then providing scholarships to children of BRI Syariah employees who are ordinary workers, Providing financing assistance for renovation of madrasah and early childhood education in Bogor, Palangkaraya and Lebak Banten and held SIMPEL (Simpanan Pelajar) activities throughout Indonesia. In 2017 BRI Syariah collaborated with Baznas to bold a Santripreneur Program namely Quail Cultivation, Then there is also one university that collaborates with BRI Syariah, namely UIN Walisongo Semarang which on February 242020 entered into a memorandum of understanding or (MoU).
\end{abstract}

Keyword: Corporate Social Responsibility BRI Syariah, Funding strategies in educational institutions 


\section{Pendahuluan}

Pendidikan dari masa ke masa adalah suatu hal yang menjadi focus dan menjadi hal yang utama dalam menghadapi serta menjalankan kehidupan. Ditiap sudutnya selalu memberikan problematika dan tantangan yang ada. Pendidikan juga sebuah komponen dalam pengembangan Sumber Daya Manusia dan juga pembangunan. Pendidikan juga sudah mengalami dan terus melakukan sebuah inovasi yang disesuaikan dalam perkembangan dan juga kompetensi manusia oleh karenanya salah satu usaha untuk mengembangkan dan meningkatkan kualitas kehidupan manusia yakni denagan Pendidikan dan hal ini juga menjadi sebab mengapa Pendidikan dapat mengalami kemajuan seperti yang telah di cantumkan didalam Undang-Undang Sistem Pendidikan Nasional atau SISDIKNAS tahun 2003 pasal 3 menyebutkan bahwa Pendidikan nasional berguna untuk mengembangkan kompetensi dan membentuk karakter serta peradaban bangsa yang bermartabat dalam rangka mencerdaskan kehidupan bangsa, bertujuan guna mengembangkan potensi peserta didik untuk bisa menjadi manusia yang beriman dan bertaqwa kepada Tuhan Yang Maha Esa, berakhlak mulia, sehat, cakap, berilmu dan kreatif serta mandiri juga menjadi warga Negara yang bertanggung jawab demokratis.

Adapun salah satu hal yang mempengaruhi proses berlangsungnya Pendidikan ialah permasalahan pendanaan atau pembiayaan Pendidikan. Jika pendanaan dan biaya sudah tercukupi maka akan mudah untuk mewujudkan tujuan Pendidikan secara optimal. Permasalahan dana Pendidikan ialah termasuk dalam komponen masukan instrumental (Instrumental input) yang lumayan penting pada menyelenggarakan Pendidikan di Lembaga-lembaga Pendidikan. didalam usaha mencapai tujuan Pendidikan, yakni tujuan yang berdasar Kualitatif dan kuantitatif, pendanaan Pendidikan mempunyai peran dalam menentukan capaian Pendidikan. sebab dalam usaha Pendidikan hampir tidak ada yang bisa mengabaikan peran pendanaan atau pembiayaan ini, oleh karena itu disebutkan proses Pendidikan pada Lembaga Pendidikan tidak bisa berjalan manakala tidak terdapat pendanaan dan juga pembiayaan didalamny. ${ }^{1}$

\footnotetext{
${ }^{1}$ Dedi Supriyadi, Satuan Biaya Pendidikan (Bandung: PT Remaja Rosdakarya, 2010), 3.
} 


\section{Strategi Pembiayaan pada Lembaga Pendidikan Islam melalui Tanggung Jawab Sosial (CSR) Studi Kasus Bank Bri Syariah}

Demi mewujudkan generasi muda yang berkualitas dan cerdas, maka salah satu solusinya ialah mengadakan dan juga menjalankan kegiatan Tanggung Jawab Sosial atau Corporate Social Responsibility pendidikan yakni kegiatan tanggung jawab social yang diselenggarakan oleh perusahaan-perusahaan di Indonesia, dengan mengadakan dan menyalurkan bantuan yang berkelanjutan serta berkesinambungan. Sebab hal ini adalah suatu sifat kepedulian perusahaan demi memajukan masyarakat Indonesia yang lebih baik. Sehingga dengan adanya CSR Pendidikan anak-anak mampu untuk belajar dengan baik dan juga semangat dalam proses pendidikan Oleh sebab itu peneliti mengambil sampel penelitian pada salah satu Bank Syariah di Indonesia yakni BRI Syariah.

\section{Metode Penelitian}

Penelitian menggambarkan dan menjelaskan kegiatan pada Bank BRI Syariah di Indonesia dengan menggunakan penelitian pustaka yakni pengumpulan data dilakukan dengan menggali informasi-informasi di media seputar CSR BRI Syariah. Penelitian ini bersifat Kualitatif dimana penelitian memaparkan dan mnejelaskan tanpa adanya perhitungan data-data. Serta dalam penggunan sumber data mengambil sumber data kedua yakni sumber data sekunder.

\section{Pembahasan}

A. Tanggung Jawab Sosial (Corporate Social Responsibility) serta Hubungannya dalam Pandangan Islam

Tanggung jawab perusahaan kepada masyarakat sekitar wilayah perusahaan ialah makna dari Tanggung Jawab Sosial atau CSR. European Commission telah mendefinisikan CSR sebagai konsep bahwa perusahaan mengambil tindakan dengan sukarela guna berkontribusi kepada lingkungan yang bersih dan masyarakat yang lebih baik. CSR menyarankan secara khusus bagi perusahaan untuk mencatat golongan pemegang kepentingan di perusahaan dan memasukkan keperluan dalam proses menentukan keputusan yang strategis serta operasional perusahaan. ${ }^{2}$ CSR atau tanggung jawab sosial dipercaya sebagai bentuk etika dalam

${ }^{2}$ Joe DesJardins Laura Hartman, Business Ethics, terj. Danti Pujianti (Jakarta: Erlangga, 2008), 161 dan 155. 
berbisnis yang dilaksanakan dalam memenuhi tujuan untuk memberikan faedah terhadap pihak atau golongan yang berkepentingan. ${ }^{3}$ Tanggung jawab social atau CSR pada perusahaan merupakan bentuk tanggung jawab etika perusahaan yang dilakukan untuk masyarakat sekitarnya. Tanggung jawab etika atau moral ini dapat ditujukan terhadap banyak hal. WBCSD (The World Business Council For Sustainable Development) lewat publikasinya "Making Good Business Sense” mendefinisikan atau menyebutkan Tanggung Jawab Sosial (Corporate Social Responsibility) sebagai "Continuing commitment by business to behave etbically and contributed to economic development while improving the quality of live of the workforce and society at large" definisi ini memberikan penjelasan bahwa tanggung jawab social yang harus dilakukan oleh perusahaan ialah sebagai suatu tindakan yang berdasar estimasi bersifat etis pada perusahaan yang ditujukan guna memperbaiki perekonmian seperti dalam peningkatan kualitas kehidupan untuk karyawan dan juga keluarganya serta memperbaiki kualitas kehidupan masyarakat yang luas maupun yang ada disekitar perusahaan. $^{4}$

Perusahaan dalam menjalankan tanggung jawabnya memfokuskan perhatiannya kepada keuntungan, masyarakat dan lingkungan. ${ }^{5}$ Adapun nama lain dari CSR ialah Corporater Philan Trophy yang bermakna kedermawanan oleh perusahaan, Corporate Community Relation yang artinya Relasi kemasyarakatan perusahaan serta Corporate Social Investmen, Community Development yakni pengembangan masyarakat. Adapun CSR didalam pandangan Islam ialah kolaborasi dari aqidah, Syariah, akhlak, serta pemahaman mengenai harta yang ada di dunia merupakan milik Allah semata. ${ }^{6}$ Dengan menerapkan CSR yang baik maka akan menimbulkan kebermanfaatan untuk perusahaan seperti:

1. Melindungi dan mendorong nama baik dan reputasi citra perusahaan tersebut.

2. Memperoleh izin dalam beroperasi secara social.

3. Membuat pengurangan resiko yang terjadi dalam bisnis perusahaan.

4. Memperluas dalam hal sumber daya untuk operasional usaha.

\footnotetext{
${ }_{3}^{3}$ Azheri Busyra, Corporate Social Responsibility Dari Voluntari Menjadi Mandatory (Jakarta: Rajawali Pers, 2011), 26.

${ }^{4}$ Nor Hadi, Corporate Social Responsibility (Yogyakarta: Graha Ilmu, 2011), 37.

${ }^{5}$ Budi Gautama Siregar, "Penerapan Corporate Social Responsibility (Csr) Dalampandangan Islam," JURIS (Jurnal Ilmiah Syariab) 14, no. 2 Juli-Desember, 2016: 135

${ }^{6}$ Juni Donni P Buchari Alma, Manajemen Bisnis Syariah (Bandung: Alfabeta, 2009), 80.
} 


\section{Strategi Pembiayaan pada Lembaga Pendidikan Islam melalui Tanggung Jawab Sosial (CSR) Studi Kasus Bank Bri Syariah}

5. Memberikan peluang untuk pasar yang lebih banyak.

6. Membuat pengurangan biaya, seperti biaya akibat dampak pembuangan limbah.

7. Menjalin serta Memperbaiki komunikasi dengan stakeholder.

8. Memperbaiki komunikasi dengan pihak yang mengatur dan mengawasi.

9. Mengembangkan semangat serta produktivitas bagi karyawan.

10. Sebagai kesempatan untuk bisa meraih penghargaan. ${ }^{7}$

Sedangkan kebermanfaatan CSR dalam hal bisnis ialah:

1. untuk investasi social sebagai sumber dari keunggulan kompetisi perusahaan dalam kurun waktu yang panjang.

2. Memperkuat daya laba serta kinerja dalam keuangan perusahaan.

3. Mengembangkan akuntabilitias serta respon positif dari para kreditor, pemasok, investor maupun konsumen.

4. Meningkatnya tanggung jawab dan semangat kerja serta produktivitas karyawan.

5. Mengurangi adanya kerentanan luapan social dan juga resistensi yang timbul dari komunitas sekitarnya.

6. Nama baik dapat meningkat.Reputasi meningkat. ${ }^{8}$

Prinsip terpenting dari CSR atau tanggung jawab social yang digunakan guna menyokong perningkatan dalam rasa tanggung jawab para pengusaha kepada masyarakat sekitar ialah:

1. Charity, bermakna bahwa semestinya kelompok atau masyarakat yang lebih berada atau kaya membantu masyarakat lain yang masih kurang beruntung semisal orang cacat, orang sakit bahkan orang yang lanjut usia.

2. Stewardship, yakni sebuah konsep yang didapat dari ajaran-ajaran bahwa individu yang kaya sudah seharusnya menganggap dirinya sebagai pemegang amanah dalam harta benda yang mereka miliki demi kebaikan masyarakat sekitarnya. Hal ini pula merupakan realisasi dari tanggung jawab social kepada masyarakat yang awam, lingkungan dan juga karyawan maupun konsumen. ${ }^{9}$

${ }^{7}$ Irham Fahmi, Manajemen Strategi Teori Dan Aplikasi (Bandung: Alfabeta, 2013).

8 Andreas Lako, Dekonstruksi CSR Dan Reformasi Paradigma Bisnis Dan Akuntansi (Jakarta: Erlangga, 2011), 90.

${ }^{9}$ Sadono Sukirno et.al, Pengantar Bisnis (Jakarta: Kencana Prenada Media Group, 2004), 353. 
Corporate Sosial Responsibility atau tanggung jawab social juga memiliki jenisjenis tersendiri dalam pelaksanaannya diantaranya:

1. Tanggung Jawab dalam hal perekonomian, tanggung jawab ini ialah yang paling mendasar. Dan ini adalah tugas para manajer yang berperan menjadi perantara dari para pemiliki perusahaan guna mengoptimalkan kesejahteraan para investor.

2. Tanggung Jawab perihal Hukum, mencerminkan suatu tugas dan kewajiban bagi perusahaan dalam menghormati undang-undang kegiatan berbisnis. Tanggung jawab hukum ialah kewajiban perusahaan untuk taat terhadap hukum yang sudah menata seluruh aktivitas bisnis.

3. Tanggung jawab etis, tanggung jawab ini dilakukan guna untuk memperbaiki perilaku para manajer atau pebisnis dengan baik, layak dan benar.

4. Tanggung jawab dalam kebebasan pengambilan keputusan atau diskresi, yakni tanggung jawab yang secara kemauannya sendiri yang dilakukan para organisasi bisnis. ${ }^{10}$

Tanggung jawab social atau CSR dalam pandangan Islam lihat pada tujuan dari syariat agama islam sendiri antara lain Maqashid al Syariah yang artinya merupakan upaya guna menciptakan, atau mewujudkan maslahah, yang bukan hanya mencari keuntungan. Berbisnis di dalam agama islam mempunyai tempat yang mulia dan strategis sebab tidak hanya diperbolehkan namun Allah memerintahkannya didalam Al-Qur'an. Seperti di dalam surah Al-Jumu'ah ayat 10 dan surah Al-Baqarah ayat 148 yang berbunyi:

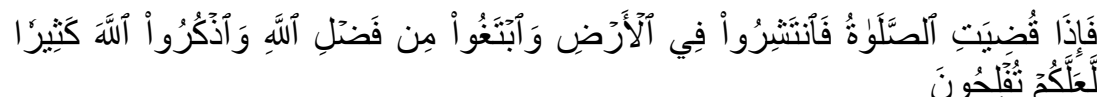
"Apabila telah ditunaikan shalat, maka bertebaranlah kamu di muka bumi; dan carilah karunia Allah dan ingatlah Allab banyak-banyak supaya kamu beruntung" (Q.S Al-Jumuah ayat 10)

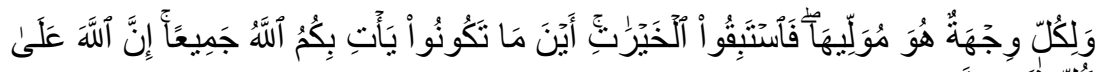

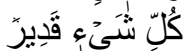

"Dan bagi tiap-tiap umat ada kiblatnya (sendiri) yang ia menghadap kepadanya. Maka berlomba-lombalah (dalam membuat) kebaikan. Di mana saja kamu berada pasti Allah akan mengumpulkan kamu sekalian (pada

${ }^{10}$ Rischard B Robinson Jr John A Pearce, Manajemen Strategis (Jakarta: Salemba Empat, 2013), 57-58. 


\section{Strategi Pembiayaan pada Lembaga Pendidikan Islam melalui Tanggung Jawab Sosial (CSR) Studi Kasus Bank Bri Syariah}

hari kiamat). Sesungguhnya Allah Maha Kuasa atas segala sesua" (Q.S Al-

Baqarah ayat 148)

Berdasarkan pandangan Islam, kewajiban melakukan tanggung jawab social atau CSR tidak serta merta berhubungan dalam memenuhi kewajiban secara moral dan hukum, namun juga sebagai strategi untuk masyarakat dan perusahaan untuk tetap bertahan dalam kurun waktu yang Panjang. Bilamana tanggung jawab social ini ditiadakan perusahaan justru akan lebih banyak menanggung beban biaya. Tetapi jika sebaliknya tanggung jawab social dilakukan dengan benar, baik dan memenuhi semua hak-hak yang bersangkutan dan masih batas kewajaran seperti keadilan dan memastikan penyaluran kekayaan dengan adil maka hal ini nantinya akan menimbulkan kebermanfaatan yang banyak dalam waktu yang Panjang untuk perusahaan itu sendiri.

Bentuk-bentuk CSR diantaranya seperti meningkatkan kepuasan, mengurangi stress karyawan, meningkatkan moral, menciptakaan suasana kerja yang sehat dan aktif serta mengembangkan penyaluran kekayaan terhadap masyarakat. Visi daripada keadlian sosia ekonomi dan distribusi atau penyaluran kekayaan yang adil dan merara juga bagian dari hal yang tidak bisa dipisahkan dari gagasan moral islam dan berdasar pada komitmennya yang pasti terhadap kemanusiaan dan persaudaraan. Adapun gagasan dalam pandangan islam yang tercermin di dalam tanggung jawab social atau CSR yakni:

1. Memelihara dan melestarikan lingkungan.

2. Usaha dalam menghapus tingkat kemiskinan.

3. Mengutamakan hal-hal yang bersifat bersih ketimbang hal-hal yang kotor meskipun hal itu nantinya mengundang keuntungan yang besar.

4. Bersikap Jujur dan amanah dalam mengemban tugas.

Keempat falsafah tersebut ialah upaya guna menyeimbangkan semua unsur kehidupan individu muslim dengan ajaran-ajaran islam, maka nantinya system perbankan islam dan keuangan dapat memberikan peran serta kontribusinya kepada capaian tujuan sosio perekonomian islam. ${ }^{11}$

${ }^{11}$ Ali Syukron, “CSR Dalam Perspektif Islam Dan Perbankan,” Jurnal Ekonomi Dan Hukum Islam 5, no. 1 2015, 1-22. 
B. Perbankan Syariah dalam Program Filantropi Serta Strategi Pembiayaan Pada Lembaga Pendidikan Islam Melalui Tanggung Jawab Sosial (CSR) Pada Bank BRI Syariah

Bank Syariah maupun unit usaha Syariah yang termasuk dalam Perbankan Syariah merupakan suatu usaha yang berasal dari perseroan terbatas. UU no 21 Tahun 2008 menjelaskan bahwa terdapat fungsi social yang berdampingan dengan fungsi ekonomis dari perbankan Syariah. Adapun peraturan undang-undang lainnya yang menitiberatkan fungsi social adalah UU no 40 tahun 2007 tentang perseroan terbatas dibuat serta disusun untuk menjadi landasan hukun dengan bertujuan terlaksankannya suasana lingkungan usaha yang kondusif, sebagau pengganti UU No 1 tahun 1995 yang tidak lagi dianggap sesuai dengan perkembangan hukum, dan juga yang dibutuhkan masyarakat. UU no 40 Tahun 2007 telah tertera peraturan mengenai CSR atau tanggung jawab social dan lingkungan yang berdasar dari sebuah kesepakatan dari perseroan terbatas guna mengambil peran seta didalam pembangunan perekonomian yang berkelanjutan guna mengembangkan kualitas kehidupan dan lingkungan yang dapat bermanfaat untuk perseroan terbatas ataupun komunitas setempat dan terlebih masyarakat umum. Dalam Bab V pasal 74 dijelaskan adanya kewajiban dari perseroan yang sedang menoperasikan kegiatan usahanya didalam suatu bidang yang berkaitan sumber daya alam maka wajib untuk melakukan tanggung jawab social atau CSR dan juga lingkungan. Hal itu harus dapat dianggarkan dan diperhitungkan untuk pendanaan dan pembiayaan perseroan yang realisasinya dilakukan dalam memfokuskan kepatutan dan juga kewajaran.

Di Indonesia perbankan Syariah selain melaksanakan tugasnya sebagai lembaga yang berfungsi menjadi tempat jasa simpanan serta pinjaman dana terhadap masyarakat serta memberikan beberapa jasa yang berhubungan dengan keuangan juga dituntuk melaksanakan kegiata yang bersifat kepedulian, kedermawanan yang berdasar kepada cinta kepaada sesama manusia diantaranya mengumpulkan, mendistribuskan, menyalurkan kedermawanan zakat dan merealisasikan program CSR atau Tanggung Jawab Sosial. Dan masih banyak kegiatan lainnya yang berhubungan dengan kedermawanan serta amal yang memiliki tujuan guna menyentuh unsur-unsur yang utama dan terpenting dalam 


\section{Strategi Pembiayaan pada Lembaga Pendidikan Islam melalui Tanggung Jawab Sosial (CSR) Studi Kasus Bank Bri Syariah}

membangun umat terutama dalam perbaikan Pendidikan, Kesehatan serta Kesejahteraan. Untuk kebermanfaatan yang lebih banyak lagi kerjasama dengan lembaga filantropi yang lain juga menjadi penting dan melihatkan adanya kebersamaan didalam proses pengembangan dan perbaikan umat dan yang paling utama adalah pengembangan atau peningkatan kualitas hidup yang mengarah pada kebaikan. ${ }^{12}$

Lembaga keuangan Syariah tidak hanya bank saja terdapat juga non bank. Lembaga keuangan Syariah dalam menjalankan operasionalnya haruslah memperhatikan beberapa prinsip seperti prinsip keadilan, kemitraan, transparasi, dan universal. Adapun pada pelaksanaan setiap transaksinya tidak dikenal adanya system bunga baik dalam perihal penghimpunan ataupun penyaluran dana dan lain-lain. Bank Syariah merupakan bank yang beroperasi dengan menggunakan prinsip-prinsip Syariah didalamnya.

Adapun diantara lembaga keuangan Syariah yakni BRI Syariah yang juga masuk dalam kategori ketiga terbesar berdasar jumlah asset yang dimilikinya. BRI Syariah dapat berkemban dan meningkat dengan signifikan jika dipandang dari segi asset, jumal pembiayaan dan jumlah pendanaan yang didapat dari pihak ketiga maupun masyarakat. Pembagian atau pengelompokan pasar yang digarap oleh BRI Syariah difokuskan untuk golongan mengenah ke bawah, maka nantinya sentuhan pada sector mikro dan menengan atau UMKM dapat dilihat secara dominan ketimbang dengan usaha kelas atas. Sebagai perusahaan yang bergerak dalam jasa Syariah, BRI Syariah sudah berkomitmen mengoperasikan dan melaksanakan program Corporate Social Responsibility atau tanggung jawab social yang memang sudah di canangkan oleh pemerintah sebagai komitmennya guna turut serta membangun perekonomian yang berkesinambungan bagi masyarakat Indonesia. ${ }^{13}$

BRI Syariah dalam menjalankan usahanya telah berkomitmen untuk menebarkan kebermanfaatan dalam dan untuk kehidupan sekitar tidak hanya mencari keuntungan semata. Maka daripada itu BRI Syariah membuat, merancang dan mengaplikasikan program tanggung jawab social perusahaan dengan

12 Abdur Razzaq, "Pengembangan Model Pembangunan Ummat Melalui Lembaga Filantropi Islam Sebagai Bentuk Dakwah Bil Hal," Intizar 20, no. 1 2016, 163-80

${ }^{13}$ Muhammad Tho'in, "Implementasi Corporate Social Responsibility (CSR) Pada Lembaga Kenangan Syariah (Studi Kasus Pada BRI Syariab Tabun 2014-2015),” Al-Tijary 2, no. 2 Juni 2018: 125 
mengikutsertakan masyarakat sekitar untuk turut berperan dan ikut serta pada usaha dan upaya pelestarian lingkungan serta memberi sokongan dalam mencapai tujuan pembangunan berkelanjutan didalam perbandingan globa, Sustainable development goals. BRI Syariah berkmitmen penuh serta berperan aktif dalam mengembangkan kualitas lingkungan dan kehiudupan yang bermanfaat untuk masyarakat maupun Perseroan dan juga komunitas-komunitas. Perseroan juga sudah mengabdikan diri dalam merealisasikan aktivitas dan kegiatan melalui tanggung jawab social atau CSR serta tanggung jawab lingkungan. Hal ini dilakukan untuk sebagai penerapan strategi BRI Syariah demi mencapai pengembangan, pertumbuhan yang dapat berkelanjutan dan menjadi investasi dalam kurun waktu yang Panjang bagi perseroan dan dalam rangka menyokong tercapainya tujuan berkelanjutan.

BRI Syariah juga sudah mempunyai kebijakan internal yang telah menjadi sebuah acuan dalam melaksanakan program Tanggung Jawab Sosial atau CSR, yang direalisasikan secara rutin dan tepat sasaran. Pelaksanannya berdasar pada surat edaran No.SE.31-DIR/OPS/06/2011 tertanggal 21 juni 2011 tentang zakat profesi pegawai BRI Syariah dan surat edaran direksi BRI Syariah No.SE.B.001PDR/03-2016 tertanggal 31 maret 2016 yakni mengenai ketetapan pemakaian dana kebajikan untuk pelaksanaan Tanggung Jawab Sosial BRI Syariah.

BRI Syariah dalam menjalankan CSR dalam bidang Pendidikan memberi program yang bernama Faedah Pendidikan yang dilakukan dan direalisasikan dengan bertujuan membantu untuk mengembangkan kualitas Pendidikan dalam masyarakat. Di tahun 2018 Perseroan telah mewujudkan sekitar 33 program yakni diantaranya seperti memberikan beasiswa kepada mahasiswa dhua'fa yang memiliki kompetensi dalam bidang akademik, mahasiswa tersebut dipilih dari 9 perguruan tinggi ternama, ada juga pemberian beasiswa untuk anak dari pegawai BRI Syariah sendiri namun yang masuk dalam golongan pegawai biasa, dan memberikan bantuan dalam merenovasi beberapa madrasah seperti madrasah di Bogor, Kemenag RI di Palangkaraya, dan renovasi madrasah PAUD di Lebak banten serta membuat program aktivitas menabung yang diberi nama SIMPEL atau Tabungan Simpanan Pelajar yang dilakukan diseluruh Indonesia. pada tahun 2017 lalu BRI Syariah menggandeng Baznas untuk mengadakan Program 


\section{Strategi Pembiayaan pada Lembaga Pendidikan Islam melalui Tanggung Jawab Sosial (CSR) Studi Kasus Bank Bri Syariah}

Santripreneur yakni Pembudidayaan Burung Puyuh. Program ini diikuti oleh 20 orang Santri Pondok Pesantren Al-Amin. Selama pelatihan yang dilaksanakan 3 hari, para santri diberi bekal pengetahuan dan praktek pembudidayaan burung puyuh. Dalam membudidayakan burung puyuh santri di bina selama 3 bulan kedepan sehingga para santri benar-benar menguasai budi daya burung puyuh. Maka BRI Syariah dan juga Baznas tidak hanya memfasilitasi pelatihan ini tetapi juga memberikan bantuan bibit burung puyuh sekaligus beserta kandangnya. BRI Syariah concern terhadap program CSR yang berkelanjutan seperti program Santripreneur ini sebab OJK bersama WWF Indonesia pada tanggal 23 November 2015 telah menetapkan BRI Syariah bersama 7 bank lainnya guna menjadi First Mover On Sustainable Banking. Yang bertujuan untuk penerapan integrase aspek lingkungan, social dan tata kelola ke dalam operasional perbankan sebagai bagian utama persiapan implementasi Sustainable finance roadmap atau peta jalan keuangan berkelanjutan lima tahun ke depan. Sustainable ialah membangun bisnis bank dalam jangka waktu Panjang dengan menyelaraskan sisi social, lingkungan dan pertimbangan ekonomi atas segala keputusan yang dibuat oleh bank. Hal ini bertujuan memnerikan kesempatan untuk bank guna mendorong dan menyokong pertumbuhan bisnis maupun sekaligus berkontribusi di dalam aspek lingkungan dan perkembangan masyarakat di masa depan. Diharapkan dari program Santripreneur ini ialah santri-santri bisa mengaplikasikan jiwa berwirausaha dan siap terjun ke masyarakat guna membina masyarakat yang tidak hanya dari sisi ilmu agama namun juga akhlak masyarakat serta membuna pula masyarakat yang membangun kemandirian ekonomi. ${ }^{14}$

Lalu ada juga salah satu perguruan tinggi yang bekerjasama dengan BRI Syariah yakni UIN Walisongo Semarang yang pada tanggal 24 Februari 2020 mengadakan nota kesepahaman atau (MoU). Dilansir pada laman pribadi UIN Walisongo menyebutkan bahwa kerjasama ini merupakan yang kedua setelah sebelumnya berhasil dan sukses pada periode pertama. Kerjasama dengan BRI Syariah sudah dimulai sejak tahun 2015 silam. Kerjasama pada periode pertama BRI Syariah membantu untuk turut dalam pengembangan kampus sebagai

${ }^{14}$ BRI Syariah, "Program BRIS Berfaedah," . 
kampus islam riset berbasis kesatuan ilmu pengetahuan untuk kemanusiaan dan peradaban. Adapun harapan UIN Walisongo ialah agar layanan BRI Syariah terutama yang berhubungan dengan CSR bisa bermanfaat bagi mahasiswa UIN yang kapasitasnya mencapai 20 ribu mahasiswa. Pada periode pertama kerjasama diwujudkan dalam bentuk pelayanan penerimaan SPP, Payroll gaji pembiayaan Karyawan, membuka layanan kas dan sebagainya. Pada periode kedua BRI Syariah telah diberi kepercayaan untuk 5 tahun kedepan. BRI Syariah juga memberikan bantuan berupa 1 mobil Pajero Sport. Harapannya kerjasama antar Lembaga ini bisa semakin intensif. Adapun strategi BRI Syariah yakni berupa layanan digitan banking hingga mencapai asset 43 Triliun. ${ }^{15}$

\section{Kesimpulan}

Tanggung jawab social atau Corporate Social Responsibility bukan saja guna melengkapi kewajiban berdasarkan hukum serta moral, namu ia hadir sebagai strategi untuk masyarakat dan juga perusahaan agar bisa bertahan dalam waktu yang Panjang. Apabila Tanggung Jawab Sosial ini ditiadakan akan berdampak pada perusahaan salah satunya banyak menanggung pembiayaan. Tetapi jika sebaliknya perusahaan melakukan Tanggung Jawab Sosial dengan baik diantaranya memastikan pendistribusian pembiayaan dengan adil dan benar, maka hal ini nantinya akan menimbulkan kebermanfaatan pada kurun waktu yang panjang bagi perusahaan. BRI Syariah dalam menjalankan CSR dalam bidang Pendidikan memberi program yang bernama Faedah Pendidikan yang bertujuan guna menyokong kualitas Pendidikan di masyarakat. Di tahun 2018 Perseroan telah menjalankan sekitar 33 kegiatan diantaranya: mengadakan pembiayaan beasiswa terhadap mahasiswa yang berprestasi yang tergolong dalam mahasiswa dhuafa di 9 perguruan tinggi, lalu memberikan beasiswa kepada anak pegawai BRI Syariah yang levelnya pekerja biasa, Memberikan bantuan pembiayaan renovasi madrasah dan PAUD di Bogor, Palangkaraya serta Lebak Banten serta mengadakan kegiatan SIMPEL (Simpanan Pelajar) di seluruh Indonesia.pada tahun 2017 lalu BRI Syariah menggandeng Baznas untuk mengadakan Program Santripreneur yakni Pembudidayaan Burung Puyuh, Lalu ada

15 TIM HUMAS UIN Walisongo, "MoU Dengan BRIsyariah, Rektor UIN Walisongo Ingin Ada CSR Bagi Mahasiswa," 2020. 


\section{Strategi Pembiayaan pada Lembaga Pendidikan Islam melalui Tanggung Jawab Sosial (CSR) Studi Kasus Bank Bri Syariah}

juga salah satu perguruan tinggi yang bekerjasama dengan BRI Syariah yakni UIN Walisongo Semarang yang pada tanggal 24 Februari 2020 mengadakan nota kesepahaman atau $(\mathrm{MoU})$.

\section{Daftar Rujukan}

Ali Syukron. "CSR Dalam Perspektif Islam Dan Perbankan.” Jurnal Ekonomi Dan Hukum Islam Volume 5, Nomor. 1 (2015)

Andreas Lako. Dekonstruksi CSR Dan Reformasi Paradigma Bisnis Dan Akuntansi. Jakarta: Erlangga, 2011.

Azheri Busyra. Corporate Social Responsibility Dari Voluntari Menjadi Mandatory. Jakarta: Rajawali Pers, 2011.

BRI Syariah. "Program BRIS Berfaedah," n.d.

Buchari Alma, Juni Donni P. Manajemen Bisnis Syariah. Bandung: Alfabeta, 2009.

Fahmi, Irham. Manajemen Strategi Teori Dan Aplikasi. Bandung: Alfabeta, 2013.

John A Pearce, Rischard B Robinson Jr. Manajemen Strategis. Jakarta: Salemba Empat, 2013.

Laura Hartman, Joe DesJardins. Business Ethics, Alih Bahasa Danti Pujianti. Jakarta: Erlangga, 2008.

Nor Hadi. Corporate Social Responsibility. Yogyakarta: Graha Ilmu, 2011.

Razzaq, Abdur. "Pengembangan Model Pembangunan Ummat Melalui Lembaga Filantropi Islam Sebagai Bentuk Dakwah Bil Hal.” Intizar 20, no. 1 (2016): 163-80. https://doi.org/10.19109/intizar.v20i1.428.

Sadono Sukirno dkk. Pengantar Bisnis. Jakarta: Kencana Prenada Media Group, 2004.

Siregar, Budi Gautama. "Penerapan Corporate Social Responsibility (Csr) Dalampandangan Islam.” JURIS (Jurnal Ilmiah Syariah) 14, no. 2 (2016): 135. https://doi.org/10.31958/juris.v14i2.303.

Supriyadi, Dedi. Satuan Biaya Pendidikan. Bandung: PT Remaja Rosdakarya, 2010. 
Tho'in, Muhammad. "Implementasi Corporate Social Responsibility (CSR) Pada Lembaga Keuangan Syariah (Studi Kasus Pada BRI Syariah Tahun 20142015).” Al-Tijary 2, no. 2 (2018): 125. https://doi.org/10.21093/at.v2i2.717.

TIM HUMAS UIN Walisongo. "MoU Dengan BRIsyariah, Rektor UIN Walisongo Ingin Ada CSR Bagi Mahasiswa," 2020. 